\title{
The Ionic Mechanism of Reperfusion-induced Early Afterdepolarizations in Feline Left Ventricular Hypertrophy
}

\author{
Tetsushi Furukawa, ${ }^{\star}$ Arthur L. Bassett, ${ }^{\star}$ Nanako Furukawa, ${ }^{*}$ Shinichi Kimura, ${ }^{*}$ and Robert J. Myerburg ${ }^{\star}$ \\ Departments of ${ }^{*}$ Medicine and ${ }^{\ddagger}$ Molecular and Cellular Pharmacology, University of Miami School of Medicine, Miami, Florida 33101
}

\begin{abstract}
Left ventricular hypertrophy (LVH) potentiates reperfusionassociated ventricular fibrillation. To study the mechanism responsible, patch-clamp techniques were used to evaluate transmembrane ionic currents during "reperfusion" after a $\mathrm{CN}^{-}$-induced metabolic surrogate for ischemia in isolated myocytes from a feline model of experimental LVH. Reperfusion caused the generation of early afterdepolarizations (EADs) from an average take-off potential of $-33 \mathrm{mV}$ in $\mathrm{LVH}$ cells but not in cells from normal hearts. $10 \mathrm{~min}$ after initiating reperfusion of normal cells, action potential duration (APD) at $\mathbf{5 0 \%}$ repolarization (APD ${ }_{50}$ ) lengthened from $198 \pm 41$ to $233 \pm 57 \mathrm{~ms}$ whereas in $L V H$ cells $A P D_{50}$ lengthened from $262 \pm 84$ to $349 \pm 131 \mathrm{~ms}(P<0.05)$. Among the $L V H$ cells, $A P D_{50}$ lengthening was significantly greater in the cells that had developed EADs. During reperfusion, steady state outward current in the voltage range of the action potential plateau (between -20 and $+20 \mathrm{mV}$ ) was reduced from the control values in $\mathrm{LVH}$ cells but not in normal cells. Reperfusion-related reduction of steady state outward current in LVH cells was abolished under experimental conditions in which $\mathrm{L}$-type $\mathrm{Ca}^{2+}$ current was isolated from other classes of currents whereas it was still observed under the condition in which pure $\mathrm{K}^{+}$currents could be recorded. Thus, reduction of steady state outward current due to the reduction of outward $\mathrm{K}^{+}$current over the action potential plateau voltage range appears to be responsible for an excessive prolongation of APD, leading to the development of EADs. (J. Clin. Invest. 1993. 91:1521-1531.) Key words: pressure overload $\bullet$ aortic constriction • reperfusion • early afterdepolarization • calcium current $\cdot$ potassium current
\end{abstract}

\section{Introduction}

Cardiac hypertrophy is a common physiological response to chronic pressure overload and is characterized by cellular enlargement accompanied by biochemical (1), electrophysiological $(2,3)$, and mechanical changes $(4)$, as well as alterations in the coronary circulation (5). Although left ventricular (LV) ${ }^{1}$

Address correspondence to Robert J. Myerburg (D-39), Division of Cardiology, Department of Medicine, University of Miami School of Medicine, P.O. Box 016960, Miami, FL 33101.

Received for publication 23 July 1992 and in revised form 13 November 1992.

1. Abbreviations used in this paper: APA, action potential amplitude; APD, action potential duration; EAD, early afterdepolarization; I-V, current to voltage; $L V$, left ventricular; $L V H$, left ventricular hypertrophy; RMP, resting membrane potential; TEA, tetraethylammonium; TTX, tetrodotoxin; VF, ventricular fibrillation.

J. Clin. Invest.

(C) The American Society for Clinical Investigation, Inc.

$0021-9738 / 93 / 04 / 1521 / 11 \quad \$ 2.00$

Volume 91, April 1993, 1521-1531 hypertrophy is an adaptive process permitting maintenance of physiological function in the face of increased work loads, it may enhance some deleterious effects of ischemia. When acute ischemia occurs in dogs with LV hypertrophy, the incidence of lethal arrhythmias and sudden cardiac death increases markedly (6). Several experimental studies demonstrated enhanced susceptibility of the hypertrophied heart to ischemic arrhythmias, and an enhanced propensity to reentrant arrhythmias has been suggested (6-8). Kohya et al. (7) reported in multicellular ventricular muscle preparations that tissues isolated from hypertrophied LV showed a greater degree of shortening of action potential duration (APD) during acute regional ischemia than did normal tissues. They suggested that this would tend to enhance dispersion of refractoriness during ischemia, between the shortened APD in the ischemic zone and the prolonged APD of the hypertrophied nonischemic zone, and would enhance the propensity to reentrant arrhythmias during ischemia. Martins et al. (8) suggested that hypertrophied hearts had a higher inducibility of ventricular tachycardia. Such hearts displayed greater endocardial-to-epicardial conduction delay in ischemic zones and responses of induced ventricular tachycardia to stimulation met two criteria for entrainment; both findings were consistent with reentrant tachycardia.

Recently, however, Taylor et al. (9) reported in an in vivo study that LV hypertrophy potentiated reperfusion-associated ventricular fibrillation (VF). Potentiation of reperfusion-associated VF, in addition to the enhanced susceptibility to ischemic arrhythmias in LV hypertrophy, may provide additional explanations for greater susceptibility of patients with LV hypertrophy to sudden cardiac death. The mechanisms for reperfusion arrhythmias have not been fully elucidated but, in contrast to ischemic arrhythmias, it has been suggested that nonreentrant mechanisms, such as automaticity or afterdepolarization-induced triggered activity, may have a prominent role (10, 11). Furthermore, Molina-Viamonte et al. (12) suggest that a specific alpha-adrenergic pathway, which induces phosphoinositide metabolism, is involved in the generation of triggered activity during reperfusion.

Delayed repolarization with prolonged APDs occurs in LV hypertrophy, a pathphysiological feature favoring the generation of early afterdepolarizations (EADs) (11). Therefore, the present study was designed to test the hypothesis that hypertrophied LV myocytes are more susceptible to development of EADs during reperfusion after an ischemic surrogate than are normal myocytes. Since EADs occur during reperfusion, patch-clamp experiments were done to characterize the ionic mechanisms responsible for reperfusion-associated EADs in hypertrophied myocytes. A preliminary report of this work has been presented (13).

\section{Methods}

This study was approved by the Institutional Review Board for Animal Research of the University of Miami. Care of the animals conformed to 
guidelines by the National Institutes of Health and the Department of Agriculture.

Preparations of animals and surgical procedure. Hypertension with secondary cardiac hypertrophy was induced in adult mongrel cats by chronic pressure overload produced by a modification of a subtotal subdiaphragmatic aortic stenosis procedure described previously (14). In 28 cats (wt $2.5-4.5 \mathrm{~kg}$; mean $3.4 \pm 0.6 \mathrm{~kg}$ ) of either sex, general anesthesia was induced with $5 \%$ isoflurane and $\mathrm{O}_{2}$ flowing at 1 liter/ min using an isoflurane-specific vaporizer (model Fluotec MK-III; Ohio Medical Products). A warm saline-filled polyethylene catheter was placed in the right brachial artery to monitor arterial blood pressure via a transducer (model P23-D; Statham Co.) connected to a polygraph (model Data Scope 22001; Grass Instrument Co., Quincy, MA). A lead II electrocardiogram was monitored throughout the surgery with a polygraph (Grass Instrument Co.).

Using standard sterile techniques, the abdomen was entered through a midline incision, the abdominal aorta was dissected, and a nonabsorbable polytetrafluoroethylene-coated polyester tie $(0$ Ethiflex ) was looped around the aorta just cranial to the renal arteries. A tie was made to constrict the aorta to $\sim 10 \%$ of the original surface diameter; this usually increased systolic blood pressure in the right brachial artery, monitored during general anesthesia, by $20-30 \mathrm{mmHg}$ over the control value. After surgery was completed, the animals recovered in a veterinary intensive care unit for $24 \mathrm{~h}$. During the early postoperative period ( 5-7 d), body temperature was recorded daily and an antibiotic (ampicillin, Rugby Laboratories, Rockville Centre, NY, $5-10 \mathrm{mg} / \mathrm{kg}$ i.m.) was administered. During the entire postoperative period, heart sounds, respiratory sounds, and skin edema were monitored daily to detect the development of congestive heart failure. 6 of the 28 cats $(21 \%)$ that underwent surgery died either just after surgery (three cats) or during a later period of pressure overload (three cats). Surviving cats were maintained for 8-13 wk (mean $10 \pm 1 \mathrm{wk}$ ) on their normal diets and water ad libitum.

Preparation of single cardiac myocytes. Single myocytes from feline LV were isolated by an enzymatic dissociation procedure (15) from 22 cats with aortic stenosis and 23 nonoperated cats. On the day of study, the animals were weighed, anesthetized with sodium pentobarbital ( 30 $\mathrm{mg} / \mathrm{kg}$, i.p.), anticoagulated with heparin sodium (400 IU/ kg, i.v.), and ventilated through an endotracheal tube and a positive-pressure pump (Harvard Apparatus, South Natick, MA). Saline-filled polyethylene catheters were placed in the right carotid and left femoral arteries, arterial blood pressure was measured, and the heart was then excised. Operated animals were free of signs of congestive heart failure, such as pulmonary or hepatic congestion or subcutaneous edema. The excised heart was quickly weighed, mounted on a Langendorff perfusion apparatus ( $60-\mathrm{cm}$ height), and was perfused retrogradely via the aorta for 5 min with nominally $\mathrm{Ca}^{2+}$-free Tyrode's solution at a rate of $10-15$ $\mathrm{ml} / \mathrm{min}$. Enzymatic digestion was achieved by recirculating the perfusion apparatus with $300 \mathrm{IU} / \mathrm{ml}$ collagenase (type II; Worthington Biochemical Corp., Freehold, NJ), 0.03\% hyaluronidase (type I-S; Sigma Chemical Co., St. Louis, MO), 0.02\% trypsin inhibitor (type II-S; Sigma Chemical Co.), and 0.1\% BSA (Sigma Chemical Co.) dissolved in Tyrode's solution containing $50 \mu \mathrm{M} \mathrm{Ca}^{2+}$. Enzymatic perfusion was continued until the solution flowed freely (12-15 min). The heart was then removed from the Langendorff apparatus. The LV was separated from the atria and the right ventricle, small pieces of the endocardial surface of the LV free wall were dissected using a fine scissors, and single cells were obtained by gentle agitation of tissue pieces in a beaker containing nominally $\mathrm{Ca}^{2+}$-free Tyrode's solution. Cells were filtered through $300-\mu \mathrm{m}$ nylon mesh, washed with Tyrode's solution containing increasingly higher concentrations of $\mathrm{Ca}^{2+}\left(0-2 \mathrm{mM} \mathrm{CaCl}_{2}\right)$, and stored in Tyrode's solution containing $2 \mathrm{mM} \mathrm{CaCl}_{2}$, at $4^{\circ} \mathrm{C}$. Cells were studied on the day of isolation.

Solutions. The composition of the Tyrode's solution was as follows (mM): $143 \mathrm{NaCl}, 4 \mathrm{KCl}, 2 \mathrm{CaCl}_{2}, 0.5 \mathrm{MgCl}_{2}, 0.33 \mathrm{NaHPO}_{4}, 5.5$ glucose, 5.5 Hepes ( $\mathrm{pH} 7.4$ with $\mathrm{NaOH})$. $\mathrm{Na}^{+}$-free solution contained the following (mM): 140 tetraethylammonium (TEA)-Cl, $2 \mathrm{CaCl}_{2}, 0.5$ $\mathrm{MgCl}_{2}, 5.5$ glucose, and 5.5 Hepes ( $\mathrm{pH} 7.4$ with TEA-OH). $\mathrm{CdCl}_{2}$ and $\mathrm{NiCl}_{2}$ were added from aqueous $0.1 \mathrm{M}$ stock solutions to the final con- centration of $0.1 \mathrm{mM}$ in the bath solution. Tetrodotoxin (TTX; Sigma Chemical Co.) and ouabain (Sigma Chemical Co.) were prepared on the day of each experiment from stock solutions to the final concentration in the bath solution indicated in the text. The pipette solution for recording transmembrane action potentials and nonisolated membrane currents in single cells contained the following $(\mathrm{mM}): 140 \mathrm{KCl}$, $1 \mathrm{CaCl}_{2}, 0.9 \mathrm{MgCl}_{2}, 5$ EGTA, and 10 Hepes ( $\mathrm{pH} 7.3$ with $\mathrm{KOH}$ ). The concentrations of free $\mathrm{Ca}^{2+}$ and $\mathrm{Mg}^{2+}$ were estimated as $3 \times 10^{-8} \mathrm{M}$ and $0.7 \mathrm{mM}$ from the apparent dissociation constants (16). The pipette solution for recording $\mathrm{K}^{+}$currents contained the following $(\mathrm{mM}): 140 \mathrm{KCl}, 1.2 \mathrm{MgCl}_{2}, 10$ EGTA, and 10 Hepes ( $\mathrm{pH} 7.3$ with $\mathrm{KOH}) . \mathrm{CaCl}$ was omitted from the pipette solution to minimize the possible contribution of $\mathrm{Ca}^{2+}$-activated currents and $\mathrm{Na}^{+}-\mathrm{Ca}^{2+}$ exchange. Under this condition, the concentration of free $\mathrm{Ca}^{2+}$ was estimated as $<2 \times 10^{-10} \mathrm{M}$ and that of $\mathrm{Mg}^{2+}$ as $0.7 \mathrm{mM}(16) . \mathrm{K}^{+}$-free pipette solution for recording $\mathrm{Ca}^{2+}$ current contained as follows ( $\left.\mathrm{mM}\right)$ : $120 \mathrm{CsCl}, 1 \mathrm{MgCl}_{2}, 10 \mathrm{EGTA}$, and $10 \mathrm{Hepes}(\mathrm{pH} 7.3$ with $\mathrm{CsOH})$ : the concentration of free $\mathrm{Ca}^{2+}$ in this solution was estimated as $\leq 2 \times 10^{-10}$ $\mathrm{M}$ and that of free $\mathrm{Mg}^{2+}$ as $0.7 \mathrm{mM}$ (16). All solutions were aerated with $100 \% \mathrm{O}_{2}$.

Electrophysiologic studies. Isolated single myocytes were placed in a recording chamber $(1 \mathrm{ml} \mathrm{vol})$ mounted on the stage of an inverted microscope (Olympus Corp., New Hyde Park, NY). The bath was continuously superfused with filtered Tyrode's solution $\left(37^{\circ} \mathrm{C}\right)$ at a rate of $3 \mathrm{ml} / \mathrm{min}$. During superfusion with Tyrode's solution containing $2 \mathrm{mM} \mathrm{CaCl}, 30-40 \%$ of the cells were $\mathrm{Ca}^{2+}$ tolerant and rod shaped. Single rod-shaped cells having smooth surfaces with clearly demarked striations were selected for the electrical measurements. Transmembrane potentials and membrane currents were recorded by the single-pipette whole-cell clamp technique (17). Pipettes were fabricated from $1.50-\mathrm{mm}$ outer diameter to $0.85-\mathrm{mm}$ inner diameter borosilicate glass (Dagan Corp., Minneapolis, $\mathrm{MN}$ ) using a five-stage horizontal puller (model P-87; Sutter Instrument Co., Novato, CA) and were coated with Sylgard (Dow Corning Corp., Midland, MI). After heat polishing the tip and filling with internal solution, each pipette had an internal tip diameter of $2.3 \mu \mathrm{m}$ and a resistance of 4-6 M. Electrical connections to the pipette and to the bath were made through $\mathrm{Ag}-\mathrm{AgCl}$ half-cell electrodes. The electrode potential was adjusted to zero current between the internal pipette solution and the external (bath) solution immediately before each cell was approached. Single cells were drawn onto the tip of the pipette by gently pressing the tip onto the cell surface. After a seal resistance of 10-100 G $\Omega$ was established by gentle suction (10-30 cm water), the cell membrane under the electrode tip was broken by further application of negative pressure. A resting membrane potential (RMP) of $-75 \mathrm{mM}$ to $-90 \mathrm{mV}$ was recorded in $>90 \%$ of the cells. Whole-cell current and membrane potential were recorded through a patch-clamp amplifier (model 8900; Dagan Corp.). Action potentials were elicited under current-clamp conditions by passing depolarizing current pulses of suprathreshold intensity $(<2 \mathrm{~ms}$ in duration) through the pipette at a rate of 0.5 or $1 \mathrm{~Hz}$. The membrane current was measured in the voltage-clamp mode and by applying various protocols of pulses as indicated in the text. Electrode resistance in series with the cell membrane was compensated by minimizing the duration of the capacitive surge on the current trace. Capacitive currents were measured during the application of $10-\mathrm{mV}$ hyperpolarizing pulses, and the area under the capacity transient $\left(I_{\text {cap }}\right)$ was integrated and used as a measure of whole cell membrane area $\left(A_{\mathrm{m}}\right)$, assuming a specific membrane capacity of $1 \mu \mathrm{F} / \mathrm{cm}^{2}$ (18). To avoid the confounding influence of difference in cell size between normal and pressure-overloaded cells, the amplitude of membrane currents were normalized to cell capacitance and expressed as $\mathrm{pA} / \mathrm{pF}$.

The stability of each preparation was verified before experimental measurements. For the experiments in which action potentials were recorded, verification was obtained by monitoring action potentials at a drive rate of $1 \mathrm{~Hz}$ for a 20 -min equilibration period. For the experiments in which $\mathrm{Ca}^{2+}$ currents were recorded, membrane currents were recorded during 800 -ms depolarizing pulses from a holding potential $\left(V_{\mathrm{h}}\right)$ of $-40 \mathrm{mV}$ to a test potential $\left(V_{\mathrm{t}}\right)$ of $0 \mathrm{mV}$ at a drive rate of $0.5 \mathrm{~Hz}$ for a 10-min equilibration period. For the experiments in which noni- 
solated currents or $\mathrm{K}^{+}$currents were recorded, membrane currents were monitored during 800-ms depolarizing pulses from a $V_{\mathrm{h}}$ of -80 $\mathrm{mV}$ to a $V_{\mathrm{t}}$ of $+30 \mathrm{mV}$, at a rate of $0.5 \mathrm{~Hz}$ for a 10 -min equilibration period. The preparations were considered stable if the APD at $0 \mathrm{mV}$ $\left(\mathrm{APD}_{0 \mathrm{mv}}\right)$, the amplitude of the negative peak of $I_{\mathrm{Ca}, \mathrm{L}}$, or the amplitude of steady state outward currents in each case did not differ by $>5 \%$ of their initial values in successive measurements. Once a stable condition was established, the specific experiments were initiated, and the preparations were maintained without significant deterioration or electrical changes for 30-40 min. Therefore, all electrophysiological studies were completed within $30 \mathrm{~min}$.

To induce metabolic inhibition and simulate "ischemia," cells were exposed to $\mathrm{CN}^{-}(19,20)$. The bath was superfused with Tyrode's solution containing $1 \mathrm{mM} \mathrm{CN}^{-}$, and action potentials or membrane currents were monitored for up to $15 \mathrm{~min}$. The bath was thereafter reperfused with normal Tyrode's solution and action potentials or membrane currents were monitored for up to $10 \mathrm{~min}$. $\mathrm{CN}^{-}$-Tyrode's solution was prepared by omitting glucose and adding $1 \mathrm{mM} \mathrm{NaCN}$ to the Tyrode's solution, and $\mathrm{pH}$ was adjusted to 7.4 with $\mathrm{HCl}$. Action potentials were recorded continuously and membrane currents were recorded every 5 min.

Data analysis. Membrane potentials were monitored on an oscilloscope and digitized on-line with a 14.4-bit resolution A/D converter (model PCM-1; Medical Systems Corp., Greenvale, NY) and stored on a videocassette recorder (model SL-HF900; Sony, Tokyo, Japan). Membrane currents were digitized on-line through a 12-bit resolution Labmaster A/D converter (TecMar Scientific Solutions, Burlingame, CA ) under the control of an IBM-AT computer and were stored on a floppy disc. Data were analyzed using the pClamp software program (Axon Instruments, Inc., Burlingame, CA).

All data were expressed as mean \pm SEM. Student's unpaired $t$ test was used to evaluate the statistical significance of differences in characteristics of experimental animals and those of action potentials in the control state between normal and hypertrophy groups. Effects of metabolic inhibition or reperfusion were analyzed with one-way analysis of variance with repeated measures, followed by the Newman-Keuls test. Statistical significance of binomial responses was evaluated with Fisher's exact test. Differences with $P<0.05$ were considered significant.

\section{Results}

Characteristics of experimental animals. Physiological and anatomical characteristics of normal and pressure-overloaded animals are summarized in Table I. Systolic blood pressure (carotid artery) and the systolic pressure gradient between the carotid and femoral arteries were significantly higher in pressure-overloaded animals than in normal animals. Total heart weight and the ratio of total heart weight to body weight

Table I. Characteristics of Animal Groups

\begin{tabular}{lccc}
\hline & $\begin{array}{c}\text { Normal } \\
(n=23)\end{array}$ & $\begin{array}{c}\text { Hypertrophy } \\
(n=22)\end{array}$ & $P$ \\
\hline SBP $(\mathrm{mmHg})$ & $135 \pm 33$ & $192 \pm 27$ & $<0.01$ \\
Gradient of SBP $(\mathrm{mmHg})$ & $1 \pm 3$ & $53 \pm 36$ & $<0.01$ \\
BW $(\mathrm{kg})$ & $3.1 \pm 0.5$ & $3.4 \pm 0.7$ & NS \\
WHW $(\mathrm{g})$ & $12.9 \pm 2.2$ & $19.0 \pm 3.6$ & $<0.01$ \\
WHW/BW ratio $(\mathrm{g} / \mathrm{kg})$ & $4.14 \pm 0.39$ & $5.74 \pm 1.04$ & $<0.01$ \\
SMA $\left(\mu \mathrm{m}^{2}\right)$ & $1246 \pm 316$ & $1654 \pm 362$ & $<0.01$
\end{tabular}

SBP, systolic blood pressure; BW, body weight; WHW, whole heart weight; SMA, surface membrane area. were significantly greater in pressure-overloaded cats. Cell surface membrane area was also significantly greater in myocytes isolated from pressure-overloaded animals than those from normal animals.

$E A D$ development. Development of arrhythmias during reperfusion after metabolic inhibition was studied in 10 normal and 11 hypertrophied myocytes at a driving rate of $1.0 \mathrm{~Hz}$ and in 13 additional normal and 14 additional hypertrophied myocytes at $0.5 \mathrm{~Hz}$. During superfusion with Tyrode's solution containing $1 \mathrm{mM} \mathrm{CN}^{-}$for $15 \mathrm{~min}$, none of the cells isolated from normal or those from hypertrophied hearts developed "arrhythmias." During reperfusion with normal Tyrode's solution for $10 \mathrm{~min}$, no cells isolated from normal hearts developed arrhythmias ( Table II ). In contrast, EADs were recorded during reperfusion of 4 of the 14 hypertrophied cells (29\%) at a driving rate of $0.5 \mathrm{~Hz}$ and 2 of the 11 hypertrophied cells (18\%) stimulated at $1.0 \mathrm{~Hz}$ (Table II and Fig. 1). The mean time interval between the initiation of reperfusion and the onset of EADs was $3.4 \pm 2.6 \mathrm{~min}$. Average take-off potential of EADs (the mean values of the most negative plateau voltage reached before the depolarization of EAD) was $-33 \pm 4 \mathrm{mV}$. The mean coupling interval between the action potential upstroke and the peak voltage of the EADs was $592 \pm 90 \mathrm{~ms}$ ( range 460-780 ms).

Effects of reperfusion on characteristics of action potentials. We compared characteristics of action potentials during metabolic inhibition and during reperfusion between normal and hypertrophied cells. Because EADs were observed more frequently at a driving rate of $0.5 \mathrm{~Hz}$ than at $1.0 \mathrm{~Hz}$, the following analyses were performed using data recorded at a drive rate of $0.5 \mathrm{~Hz}$. Characteristics of action potentials before exposure to $\mathrm{CN}^{-}$(control) are summarized in Table III. APD was significantly longer in cells isolated from hypertrophied hearts than those from normal hearts whereas neither RMP nor action potential amplitude (APA) was significantly different between the two cell types.

Representative recordings of action potentials in a normal cell and a hypertrophied cell before and during exposure to $\mathrm{CN}^{-}$and during reperfusion are shown in Fig. 2. In both normal and hypertrophied cells, APD was shortened during superfusion with $\mathrm{CN}^{-}$-Tyrode's solution, and was prolonged during reperfusion with normal Tyrode's solution. In Fig. 3, $\mathrm{APD}_{90}$, RMP, and APA at 5, 10, and 15 min after initiating superfusion with $\mathrm{CN}^{-}$-Tyrode's solution and 5 and $10 \mathrm{~min}$ after initiating reperfusion with normal Tyrode's solution are expressed as a fraction of the control values in normal $(n=13)$ and hypertrophied cells $(n=14)$. At $15 \mathrm{~min}$ after initiation of superfusion with $\mathrm{CN}^{-}$-Tyrode's solution, the magnitude of reductions in $\mathrm{APD}_{90}$ and $\mathrm{APD}_{50}$ were significantly greater in hypertrophied cells (upper left and right, Fig. 3 and Table IV). Moreover, both 5 and $10 \mathrm{~min}$ after initiating reperfusion with normal Tyrode's solution, the lengthening of $\mathrm{APD}_{90}$ and $\mathrm{APD}_{50}$ was significantly greater in hypertrophied cells (Fig. 3, top, and Table IV). Neither RMP nor APA changed significantly during superfusion with $\mathrm{CN}^{-}$-Tyrode's solution or during reperfusion with normal Tyrode's solution (Fig. 3, bottom). The observation that reperfusion induced greater propensity to EADs concomitant with greater APD prolongation in hypertrophied cells is consistent with the suggestion that the lengthening of APD within the plateau voltage range is critical for the development of EAD. To further confirm this suggestion, we carried out a subgroup analysis to compare the changes in APD during superfusion with $\mathrm{CN}^{-}$-Tyrode's solution and its washout between hypertrophied cells that had de- 
Table II. Probability of Developing EADs during Reperfusion

\begin{tabular}{cccr}
\hline Driving rate & Normal & Hypertrophy & $P$ \\
\hline$H z$ & & & \\
1 & $0 / 10(0 \%)$ & $2 / 11(18 \%)$ & NS \\
0.5 & $0 / 13(0 \%)$ & $4 / 14(29 \%)$ & 0.5 \\
\hline
\end{tabular}

veloped EADs and those that had not among Fig. 4. The shortening of APD during superfusion with $\mathrm{CN}^{-}$-Tyrode's solution and APD prolongation during reperfusion with normal Tyrode's solution were significantly greater in cells that had developed EADs (Fig. 4 and Table V).

We also studied the characteristics of action potentials before exposure to $\mathrm{CN}^{-}$(basal values), comparing hypertrophied cells that had developed EADs during reperfusion to those that had not. Under baseline conditions, the APDs of hypertrophied cells that had developed EADs during reperfusion had longer durations whereas neither RMP nor APA was significantly different between the two cell types. Control $\mathrm{APD}_{90}$ was $376 \pm 46 \mathrm{~ms}$ in hypertrophied cells with EADs $(n=4)$ versus $265 \pm 18 \mathrm{~ms}$ in those without EADs $(n=10)(P<0.01)$; the corresponding values for $\mathrm{APD}_{50}$ were $346 \pm 45$ and $235 \pm 17 \mathrm{~ms}$, respectively $(P<0.01)$.

Effects of reperfusion on membrane currents. To elucidate ionic mechanisms underlying greater APD prolongation and higher incidence of EAD development in hypertrophied myocytes during reperfusion, voltage-clamp studies were carried out under several experimental conditions. Nonisolated membrane currents were first elicited by 800 -ms-long steps from a $V_{\mathrm{h}}$ of $-80 \mathrm{mV}$ to various test potentials $\left(V_{\mathrm{t}}\right)$ between -90 and $+60 \mathrm{mV}$ in $10-\mathrm{mV}$ steps. Fig. $5 \mathrm{~A}$ displays representative tracings at a $V_{\mathrm{t}}$ of $-10 \mathrm{mV}$ for a normal cell (top) and a hypertrophied cell (bottom). In both cell types, superfusion with $\mathrm{CN}^{-}-$ Tyrode's solution shifted membrane current positively (marked by closed squares) whereas reperfusion with normal Tyrode's solution shifted membrane current negatively (indicated by open circles). During reperfusion with normal Tyrode's solution, in normal cells, membrane current was slightly more positive than the control level whereas in hypertrophied cells reperfusion shifted membrane current more negative than the control level. The current level $600 \mathrm{~ms}$ after the onset of the voltage steps was measured because this was the approximate timing of EAD development (the mean coupling interval between the action potential upstroke and the peak voltage of
EADs was $592 \pm 90 \mathrm{~ms})$. Fig. $5 B$ shows the averaged currentto-voltage (I-V) relationships obtained using the current density (the amplitude normalized to cell membrane capacitance) in the control state, 15 min after initiating superfusion with $\mathrm{CN}^{-}$-Tyrode's solution, and $10 \mathrm{~min}$ after initiating reperfusion with normal Tyrode's solution for normal cells ( $n=18$, left ) and for hypertrophied cells $(n=16$, right $)$. In both normal and hypertrophied cells, during superfusion with $\mathrm{CN}^{-}-\mathrm{Ty}-$ rode's solution, inward current at a $V_{\mathrm{t}}$ of $-90 \mathrm{mV}$ decreased whereas outward current at $V_{\mathrm{t}}$ more positive than $-30 \mathrm{mV}$ increased; however, the magnitude of these changes in the steady state I-V curve was not significantly different between the two cell types. During reperfusion with normal Tyrode's solution, in both normal and hypertrophied cells, inward current at a $V_{\mathrm{t}}$ of $-90 \mathrm{mV}$ in the steady state $\mathrm{I}-\mathrm{V}$ curve increased and returned close to the control values. Outward current at $V_{\mathrm{t}}$ more positive than $-30 \mathrm{mV}$ decreased and returned close to the control level in normal cells whereas in hypertrophied cells outward current decreased to values less than the control level at $V_{\mathrm{t}}$ between -20 and $+20 \mathrm{mV}$ (marked by asterisks in Fig. $5 \mathrm{~B}$ ).

Effect of reperfusion on $\mathrm{Ca}^{2+}$ currents. Many classes of currents, including L-type $\mathrm{Ca}^{2+}$ current $\left(I_{\mathrm{Ca}, \mathrm{L}}\right)$ and several $\mathrm{K}^{+}$ currents, contribute to the configuration of the action potential plateau and might be responsible for negative shift of steady state currents over the voltage range of the action potential plateau during reperfusion of hypertrophied cells. We first compared alterations in $I_{\mathrm{Ca}, \mathrm{L}}$ during reperfusion between normal and hypertrophied cells. To isolate $I_{\mathrm{Ca}, \mathrm{L}}$, we substituted $\mathrm{TEA}^{+}$for $\mathrm{Na}^{+}$and added $12.5 \mu \mathrm{M}$ TTX to the bath solution to block $\mathrm{Na}^{+}$current $\left(I_{\mathrm{Na}}\right) . \mathrm{K}^{+}$currents were eliminated with internal $\mathrm{CsCl}_{2}(130 \mathrm{mM})$ and external TEA-Cl ( $\left.140 \mathrm{mM}\right)$. The pipette solution was free of $\mathrm{CaCl}_{2}$ and was buffered with 10 mM EGTA to minimize the contribution of $\mathrm{Ca}^{2+}$-activated currents and $\mathrm{Na}^{+}-\mathrm{Ca}^{2+}$ exchange currents. $10 \mu \mathrm{M}$ ouabain was added to the bath solution to eliminate currents through $\mathrm{Na}^{+}-\mathrm{K}^{+}$pump. To elicit $I_{\mathrm{Ca}, \mathrm{L}}, V_{\mathrm{h}}$ was set at $-40 \mathrm{mV}$ to inactivate $I_{\mathrm{Na}}$ and T-type $\mathrm{Ca}^{2+}$ currents $\left(I_{\mathrm{Ca}, \mathrm{T}}\right)$ (if present), and the membrane potential was clamped for $800 \mathrm{~ms}$ to a $V_{\mathrm{t}}$ between -90 and $+50 \mathrm{mV}$ in $10-\mathrm{mV}$ steps at intervals of $2 \mathrm{~s}$. Fig. $6 \mathrm{~A}$ displays representative tracings of the early portions of $I_{\mathrm{Ca}, \mathrm{L}}$ for a normal cell (top) and for a hypertrophied cell (bottom) to assess changes in the negative peak current. In both cell types, the amplitude of $I_{\mathrm{Ca}, \mathrm{L}}$ decreased during superfusion with $\mathrm{CN}^{-}-$ Tyrode's solution whereas during reperfusion with normal Tyrode's solution the amplitude of $I_{\mathrm{Ca}, \mathrm{L}}$ increased from the values during superfusion with $\mathrm{CN}^{-}$-Tyrode's solution but did
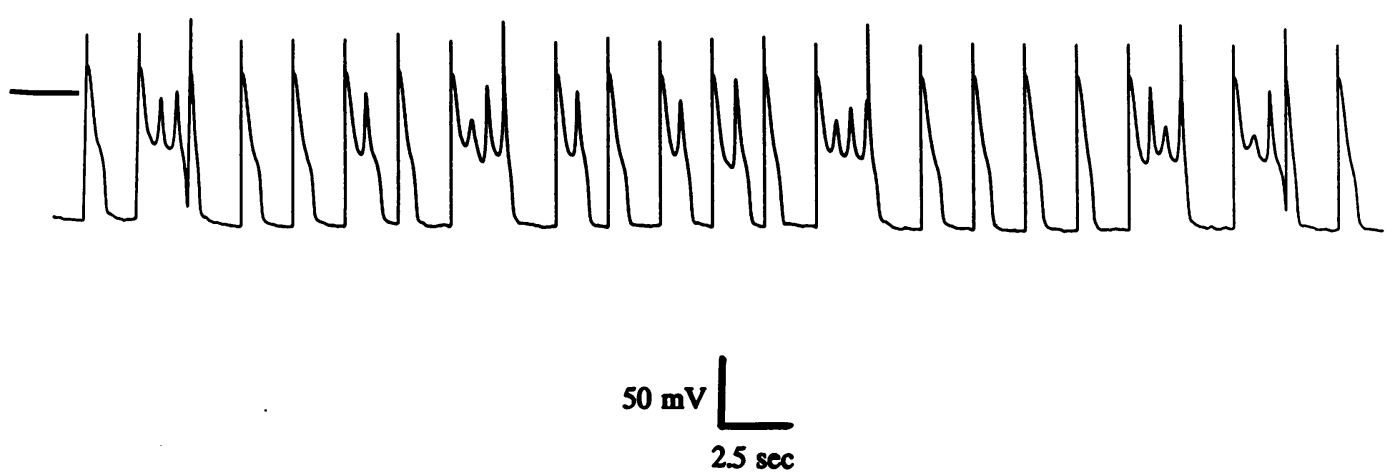

Figure 1. Reperfusion-induced EADs. Representative tracing of transmembrane action potentials recorded during washout of $\mathrm{CN}^{-}$in a hypertrophied cell. Frequent development of EADs was observed. Action potentials were elicited at a rate of $0.5 \mathrm{~Hz}$. 
Table III. Characteristics of Action Potential in the Control State

\begin{tabular}{lccc}
\hline & $\begin{array}{c}\text { Normal } \\
(n=13)\end{array}$ & $\begin{array}{c}\text { Hypertrophy } \\
(n=14)\end{array}$ & $P$ \\
\hline $\mathrm{APD}_{90}(\mathrm{~ms})$ & $234 \pm 45$ & $293 \pm 86$ & $<0.05$ \\
$\mathrm{APD}_{50}(\mathrm{~ms})$ & $198 \pm 41$ & $262 \pm 84$ & $<0.01$ \\
$\mathrm{RMP}(\mathrm{mV})$ & $-85 \pm 6$ & $-82 \pm 5$ & NS \\
APA $(\mathrm{mV})$ & $123 \pm 8$ & $122 \pm 13$ & NS
\end{tabular}

$\mathrm{APD}_{90}, \mathrm{APD}$ at $90 \%$ repolarization; $\mathrm{APD}_{50}$, $\mathrm{APD}$ at $50 \%$ repolarization; RMP, resting membrane potential; APA, action potential amplitude.

not completely recover to the control values. Fig. $6 B$ shows the averaged $\mathrm{I}-\mathrm{V}$ relationships of the negative peak of $I_{\mathrm{Ca}, \mathrm{L}}$ in the control state, 15 min after initiating superfusion with $\mathrm{CN}^{-}-$ Tyrode's solution, and $10 \mathrm{~min}$ after initiating reperfusion with normal Tyrode's solution for normal ( $n=19$, left $)$ and hypertrophied cells $(n=24$, right $)$. The decrease in the amplitude of $I_{\mathrm{Ca}, \mathrm{L}}$ during superfusion with $\mathrm{CN}^{-}$-Tyrode's solution was significantly greater in hypertrophied cells at $V_{\mathrm{t}}$ between -10 and $+20 \mathrm{mV}(P<0.05)$. During reperfusion with normal Tyrode's solution, the recovery of the amplitude of $I_{\mathrm{Ca}, \mathrm{L}}$ was slightly greater in normal cells. The differences in the recovery of peak amplitude of $I_{\mathrm{Ca}, \mathrm{L}}$ between the two cell types were statistically significant at a $V_{\mathrm{t}}$ of $0 \mathrm{mV}(P<0.05)$. The difference in the extent of recovery of $I_{\mathrm{Ca}, \mathrm{L}}$ between normal and hypertrophied cells, however, could not explain the greater APD prolongation in hypertrophied cells during reperfusion. It is generally believed that $I_{\mathrm{Ca}, \mathrm{L}}$ declines in amplitude over time during wholecell clamp experiments and replacement of the intracellular solution by an artificial salt solution ("run-down") (21). To determine whether the possible difference in the rate of rundown of $I_{\mathrm{Ca}, \mathrm{L}}$ between normal and hypertrophied cells affected our analysis, we monitored $I_{\mathrm{Ca}, \mathrm{L}}$ up to $30 \mathrm{~min}$ without exposure to $\mathrm{CN}^{-}$in four normal cells and four hypertrophied cells. We found no significant difference in the magnitude of run-down in $I_{\mathrm{Ca}, \mathrm{L}}$ between normal and hypertrophied cells; at $30 \mathrm{~min}$ after establishment of the whole-cell configuration, the peak amplitude of $I_{\mathrm{Ca}, \mathrm{L}}$ at a $V_{\mathrm{t}}$ of $0 \mathrm{mV}$ decreased to $76 \pm 17 \%$ of the control value in normal cells and $73 \pm 17 \%$ in hypertrophied cells (NS for normal vs. hypertrophy).

We next determined whether the washout of $\mathrm{CN}^{-}$affected the slowly inactivating component of $I_{\mathrm{Ca}, \mathrm{L}}$ differently between normal and hypertrophied myocytes, another possible explanation of the different extent of APD prolongation during reperfusion. $I_{\mathrm{Ca}, \mathrm{L}}$ was induced with the same voltage-step protocol as used for the measurement of peak amplitude of $I_{\mathrm{Ca}, \mathrm{L}}$, and the current level was measured $600 \mathrm{~ms}$ after the onset of the voltage step (Fig. $7 \mathrm{~A}$ ). Fig. $7 \mathrm{~B}$ depicts the averaged I-V relationships of $I_{\mathrm{Ca}, \mathrm{L}}$ at $600 \mathrm{~ms}$ in the control state, $15 \mathrm{~min}$ after initiating superfusion with $\mathrm{CN}^{-}$-Tyrode's solution, and $10 \mathrm{~min}$ after initiating reperfusion with normal Tyrode's solution for normal ( $n=19$, left $)$ and hypertrophied cells $(n=24$, right $)$. Neither superfusion with $\mathrm{CN}^{-}$-Tyrode's solution nor reperfusion with normal Tyrode's solution significantly affected the I-V relationships of $I_{\mathrm{Ca}, \mathrm{L}}$ at $600 \mathrm{~ms}$ in normal or hypertrophied cells.

Effects of reperfusion on $\mathrm{K}^{+}$currents. We next determined whether reperfusion altered $\mathrm{K}^{+}$currents differently between normal and hypertrophied cells. To isolate $\mathrm{K}^{+}$currents, we added $12.5 \mu \mathrm{M}$ TTX to the bath solution to block $\mathrm{Na}^{+}$current $\left(I_{\mathrm{Na}}\right) . I_{\mathrm{Ca}, \mathrm{L}}$ was eliminated by adding $0.1 \mathrm{mM} \mathrm{CdCl}_{2}$ to the bath solution, and $I_{\mathrm{Ca}, \mathrm{T}}$ by $0.1 \mathrm{mM} \mathrm{NiCl}$. The pipette solution was free of $\mathrm{CaCl}_{2}$ and was buffered with $10 \mathrm{mM}$ EGTA to minimize the contribution of $\mathrm{Ca}^{2+}$-activated currents and $\mathrm{Na}^{+}-\mathrm{Ca}^{2+}$ exchange currents. $10 \mu \mathrm{M}$ ouabain was added to the bath solution to eliminate currents through $\mathrm{Na}^{+}-\mathrm{K}^{+}$pump. $\mathrm{K}^{+}$currents were elicited by 800 -ms-long steps from a $V_{\mathrm{h}}$ of $-80 \mathrm{mV}$ to various $V_{\mathrm{t}}$ between -90 and $+60 \mathrm{mV}$ in $10-\mathrm{mV}$ steps. Representative tracings at a $V_{\mathrm{t}}$ of $-10 \mathrm{mV}$ are shown for a normal cell (top) and a hypertrophied cell (bottom) in Fig. $8 \mathrm{~A}$. In both cell types, superfusion with $\mathrm{CN}^{-}$-Tyrode's solution shifted $\mathrm{K}^{+}$ current positively (marked by closed squares) whereas reperfusion with normal Tyrode's solution shifted $\mathrm{K}^{+}$current negatively (marked by open circles). During reperfusion with normal Tyrode's solution, in a normal cell, membrane current was still slightly more positive than the control level whereas in a hypertrophied cell reperfusion shifted membrane current more

\section{CONTROL $\quad 1 \mathrm{mM} \mathrm{CN}^{-15} \mathrm{~min} \quad$ WO $10 \mathrm{~min}$}

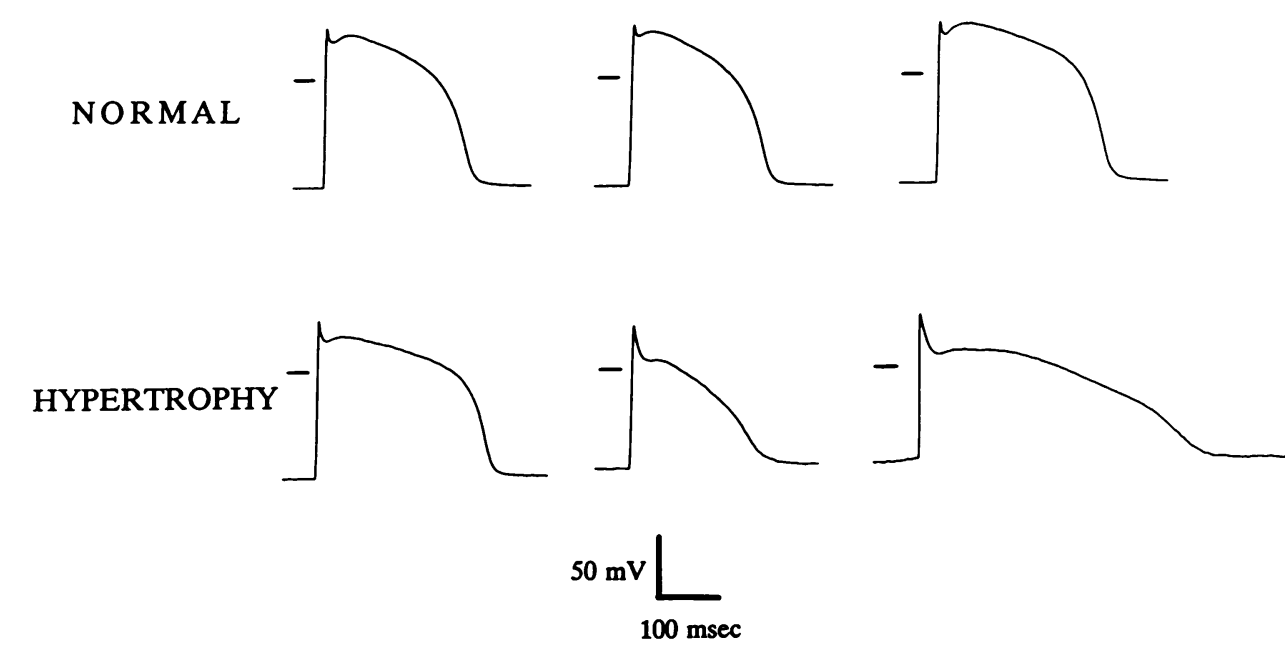

Figure 2. Representative recordings of the effects of $\mathrm{CN}^{-}$and its washout on transmembrane action potential. Recordings of action potentials are shown in the control state, 15 min after initiating superfusion with $\mathrm{CN}^{-}$-Tyrode's solution, and 10 min after initiating reperfusion with normal Tyrode's solution for a normal cell (top) and for a hypertrophied cell (bottom). Action potentials were elicited at a rate of $0.5 \mathrm{~Hz}$. Zero voltage levels are indicated by the short solid lines on the left of each panel. $W O$, washout. 

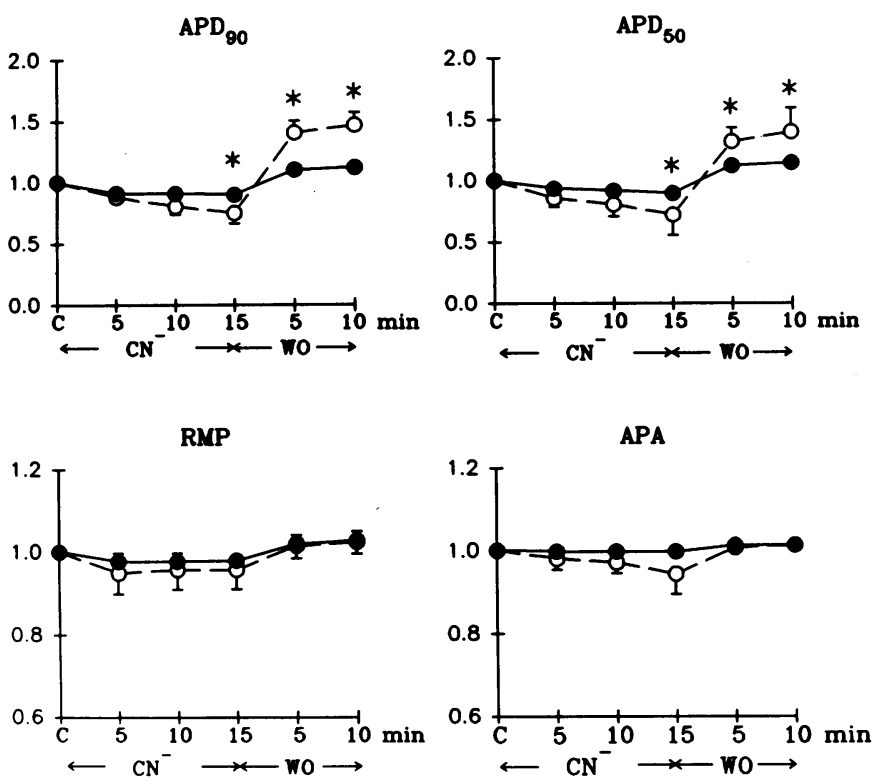

$$
\text { ( } n=13)
$$

O Hypertrophy $(\mathrm{n}=14)$
Figure 3. Effects of $\mathrm{CN}^{-}$and its washout on characteristics of action potentials. $\mathrm{APD}_{90}$ (top left), $\mathrm{APD}_{50}$ (top right), RMP (bottom left), and APA (bottom right) expressed as a fraction of the control values at 5,10 , and 15 min after initiating superfusion with $\mathrm{CN}^{-}$-Tyrode's solution and at 5 and $10 \mathrm{~min}$ after initiating reperfusion with normal Tyrode's solution in normal cells (closed circles, $n=13$ ) and in hypertrophied cells (open circles, $n=14) .{ }^{*} P<0.05$. negative than the control level. Fig. $8 B$ shows the averaged I-V relationships of the $\mathrm{K}^{+}$current measured at $600 \mathrm{~ms}$ from the onset of voltage clamps in the control state, $15 \mathrm{~min}$ after initiating superfusion with $\mathrm{CN}^{-}-$Tyrode's solution, and $10 \mathrm{~min}$ after initiating reperfusion with normal Tyrode's solution for normal $(n=12$, left $)$ and hypertrophied cells $(n=12$, right $)$. In both cell types, during superfusion with $\mathrm{CN}^{-}$-Tyrode's solution, inward current at a $V_{\mathrm{t}}$ of $-90 \mathrm{mV}$ in the steady state $\mathrm{I}-\mathrm{V}$ curve for isolated $\mathrm{K}^{+}$current decreased whereas outward current at $V_{\mathrm{t}}$ more positive than $-30 \mathrm{mV}$ for normal cells and at $V_{\mathrm{t}}$ more positive than $-40 \mathrm{mV}$ for hypertrophied cells increased; however, $\mathrm{CN}^{-}$-induced changes in the steady state $\mathrm{K}^{+}$ currents were not significantly different between the two cell types. During reperfusion with normal Tyrode's solution, in both normal and hypertrophied cells, inward current at a $V_{t}$ of $-90 \mathrm{mV}$ in the steady state I-V curve increased and returned close to the control values. Outward current at $V_{t}$ more positive than $-30 \mathrm{mV}$ decreased and recovered close to the control level in normal cells whereas in hypertrophied cells outward current decreased less than the control level at $V_{\mathrm{t}}$ between -30 and $+10 \mathrm{mV}$ (marked by asterisks in Fig. $8 \mathrm{~B}$ ).

\section{Discussion}

The present study demonstrates that hypertrophied LV myocytes may generate EADs and bursts of triggered impulses during reperfusion after a metabolic inhibition surrogate for ischemia. EADs were not observed in normal cells under the same condition. Reperfusion-induced EADs in hypertrophied cells are associated with greater prolongation of action potential plateau caused by the reduction in the steady state outward current.

Before discussing the relevance of the data in the present study, some characteristics of the study protocol must be considered. In in vivo experiments the incidence of reperfusion arrhythmias is directly dependent on the duration of the ischemia period $(11,13)$. In the feline model of occlusion-reperfusion, the incidence of reperfusion-associated VF was relatively high $(47-62 \%)$, with reperfusion established after $20 \mathrm{~min}$ of coronary occlusion whereas it was significantly less after a 10min occlusion (13\%) (23). In the current studies we used 15 min of metabolic inhibition before reperfusion. This period was chosen because transmembrane action potentials and

Table IV. Changes in Action Potential Characteristics during and after Exposure to $\mathrm{CN}^{-}$

\begin{tabular}{|c|c|c|c|c|c|c|c|c|}
\hline & \multicolumn{2}{|c|}{ RMB } & \multicolumn{2}{|c|}{ APA } & \multicolumn{2}{|c|}{$\mathrm{APD}_{\mathbf{s 0}}$} & \multicolumn{2}{|c|}{$\mathrm{APD}_{90}$} \\
\hline & $\mathbf{N}$ & H & $\mathrm{N}$ & H & $\mathbf{N}$ & H & $\mathbf{N}$ & $\mathbf{H}$ \\
\hline & \multicolumn{2}{|c|}{$-m V$} & \multicolumn{2}{|c|}{$m V$} & \multicolumn{2}{|c|}{$m s$} & \multicolumn{2}{|c|}{$m s$} \\
\hline Control & $85 \pm 5$ & $83 \pm 5$ & $124 \pm 6$ & $123 \pm 12$ & $198 \pm 41$ & $262 \pm 84^{*}$ & $234 \pm 45$ & $293 \pm 86^{*}$ \\
\hline $\mathrm{CN}^{-} 15 \mathrm{~min}$ & $83 \pm 7$ & $80 \pm 8$ & $124 \pm 7$ & $116 \pm 18$ & $177 \pm 47$ & $193 \pm 68$ & $210 \pm 47$ & $212 \pm 53$ \\
\hline Washout $10 \mathrm{~min}$ & $88 \pm 8$ & $85 \pm 7$ & $127 \pm 12$ & $125 \pm 15$ & $33 \pm 57$ & $349 \pm 131^{*}$ & $267 \pm 69$ & $441 \pm 123^{*}$ \\
\hline
\end{tabular}

Data are expressed as mean $\pm \mathrm{SD} ; \mathrm{N}$, normal myocytes; $\mathrm{H}$, hypertrophied myocytes. $n=13$ in normal and $n=14$ in hypertrophy. RMP, Resting membrane potential; APA, action potential amplitude $\mathrm{APD}_{50}$ and $\mathrm{APD}_{90}$, action potential duration at 50 and $90 \%$ repolarization, respectively. ${ }^{*} P<0.05$ normal vs. hypertrophy. 


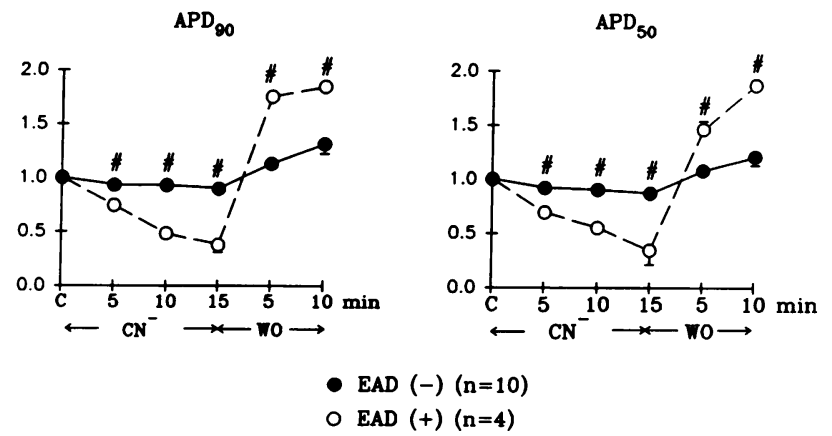

Figure 4. Changes in APD in hypertrophied cells with and without development of EADs. $\mathrm{APD}_{90}$ (left) and $\mathrm{APD}_{50}$ (right) expressed as a fraction of the control values at 5,10 , and $15 \mathrm{~min}$ after initiating superfusion with $\mathrm{CN}^{-}$-Tyrode's solution and at 5 and $10 \mathrm{~min}$ after initiating reperfusion with normal Tyrode's solution in hypertrophied cells that had not developed EADs (closed circles, $n=10$ ) and in hypertrophied cells that had developed EADs (open circles, $n=4$ ). $\# P<0.01$.

membrane currents are relatively stable for only 30-40 min after establishing the whole-cell clamp mode and replacing intracellular solution with an artificial salt solution. This time frame is in agreement with the report that the rate of run-down of $I_{\mathrm{Ca}, \mathrm{L}}$ is relatively slow for up to $30 \mathrm{~min}$ after breaking the membrane patch under the suction pipette tip (21).

The severity of metabolic inhibition may also influence the incidence of reperfusion arrhythmias. In the present experiments we used $1 \mathrm{mM} \mathrm{CN}^{-}$to induce metabolic inhibition. In previous experiments we had observed that exposure to relatively high-concentration $\mathrm{CN}^{-}(5 \mathrm{mM})$ shortened APD excessively and created a sharply spiked action potential configuration, with elimination of the plateau phase, in both normal and hypertrophied cells (24). In contrast, the shortening of APD during exposure to $1 \mathrm{mM} \mathrm{CN}^{-}$for up to $20 \mathrm{~min}$ was more moderate, but the magnitude of decrease was significantly greater in hypertrophied cells than normal cells. Thus, our data may be relevant for reperfusion arrhythmias after a relatively mild metabolic inhibition for a short time period, a condition that may be similar to some clinical circumstances in which coronary artery spasm induces arrhythmias as a result of either ischemia, reperfusion, or both (25). In experiments with longer or more severe degrees of metabolic inhibition, the development of EADs might be more frequent and they may occur even in normal cells.

Reperfusion of the ischemic myocardium is frequently associated with the development of malignant ventricular arrhythmias (23). A recent in vivo experiment demonstrated that LV hypertrophy enhanced the development of reperfusion-associated VF (9). Taylor et al. (9) demonstrated that reperfusion-associated VF occurred in 7 of $17 \mathrm{dogs}(41 \%)$ with LV hypertrophy versus 1 of $28 \operatorname{dogs}(6 \%)$ without hypertrophy. Although the mechanisms for reperfusion arrhythmias have not been fully elucidated, it has been suggested that nonreentrant mechanisms, including afterdepolarization-induced triggered activity, may have a predominant role (10-12). The characteristics of some forms of reperfusion arrhythmias observed clinically support this concept (25), especially after relatively brief periods of ischemia. The present study demon- strates that single myocytes isolated from hypertrophied ventricles are highly susceptible to development of EADs during reperfusion after the metabolic inhibition surrogate for ischemia. In addition to the possibly greater propensity of hypertrophied hearts to ischemia-induced reentrant arrhythmias, the enhanced propensity to generate reperfusion-induced EAD may partially underlie the susceptibility of patients with LV hypertrophy to sudden cardiac death, although our single-cell study design precluded reentrant mechanisms.

One may question the discrepancy between the timing between the onset of EADs in the present study and the onset of reperfusion arrhythmias in in vivo studies. In the clinical setting or in vivo experiments, reperfusion arrhythmias start to occur within several seconds after the coronary circulation is reestablished (11). In the present study, however, the mean time interval between the initiation of reperfusion and the onset of EADs development was 3.4 min (range 2.1-5.7 $\mathrm{min}$ ). This time discrepancy could be accounted by the differences in conditions between the in vivo and the in vitro studies. Priori et al. (23) observed in vivo that reperfusion-induced EADs started to occur at the moment of reperfusion whereas Ferrier et al. (26) reported in an in vitro study that reperfusion-induced delayed afterdepolarizations were initiated $5.3 \pm 0.6 \mathrm{~min}$ after reperfusion. The loss of autonomic nervous innervation in vitro may influence the time frame of onset of reperfusion arrhythmias, since alpha- (27) and beta-adrenergic (28) stimulation enhances the amplitude and incidence of cesium-induced EADs. As suggested previously, reperfusion arrhythmias may be based on multiple underlying mechanisms, and earlier onset of reperfusion arrhythmias could simply be reflecting mechanisms different from the relatively delayed onset of EADs observed in our study. In fact, abrupt reperfusion of ischemic myocardium results in an initial shortening of refractory period within seconds, whereas with sustained reperfusion of $>30 \mathrm{~s}$, refractory periods and APD in the previously ischemic region lengthen beyond preischemic values (29). EADs can be induced in isolated tissue by a variety of interventions that lengthen APD, providing a condition that permits the cellular membrane to carry the depolarizing charge through inward current channels that have recovered from inactivation.

Table V. Changes in Action Potential Duration in Hypertrophied Cells with and without Development of EADs

\begin{tabular}{|c|c|c|c|c|}
\hline & \multicolumn{2}{|c|}{$\mathrm{APD}_{\mathbf{5 0}}$} & \multicolumn{2}{|c|}{$\mathrm{APD}_{90}$} \\
\hline & $\operatorname{EAD}(-)$ & $\operatorname{EAD}(+)$ & $\operatorname{EAD}(-)$ & $\operatorname{EAD}(+)$ \\
\hline & \multicolumn{2}{|c|}{$m s$} & \multicolumn{2}{|c|}{$m s$} \\
\hline Control & $235 \pm 17$ & $346 \pm 45^{*}$ & $265 \pm 18$ & $376 \pm 46^{*}$ \\
\hline $\mathrm{CN}^{-} 15 \mathrm{~min}$ & $203 \pm 19$ & $119 \pm 34$ & $233 \pm 37$ & $143 \pm 43$ \\
\hline Washout $10 \mathrm{~min}$ & $296 \pm 30$ & $636 \pm 116^{*}$ & $336 \pm 51$ & $688 \pm 137^{*}$ \\
\hline
\end{tabular}

Data are expressed as mean $\pm \mathrm{SD}$. $\mathrm{APD}_{50}$ and $\mathrm{APD}_{90}$, action potential duration at 50 and $90 \%$ repolarization, respectively; EAD (+) and EAD (-), cells with and without development of early after depolarizations, respectively.

${ }^{*} P<0.01$ : $\operatorname{EAD}(-)$ vs. $\operatorname{EAD}(+)$. 
(A)
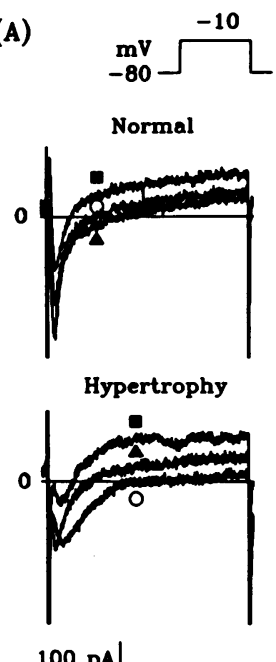

$200 \mathrm{msec}$
(B)

$$
\begin{array}{cc}
\text { Normal }(n=18) & \text { Hypertrophy }(n=16) \\
\mathrm{pA} / \mathrm{pF} & \mathrm{pA} / \mathrm{pF}
\end{array}
$$
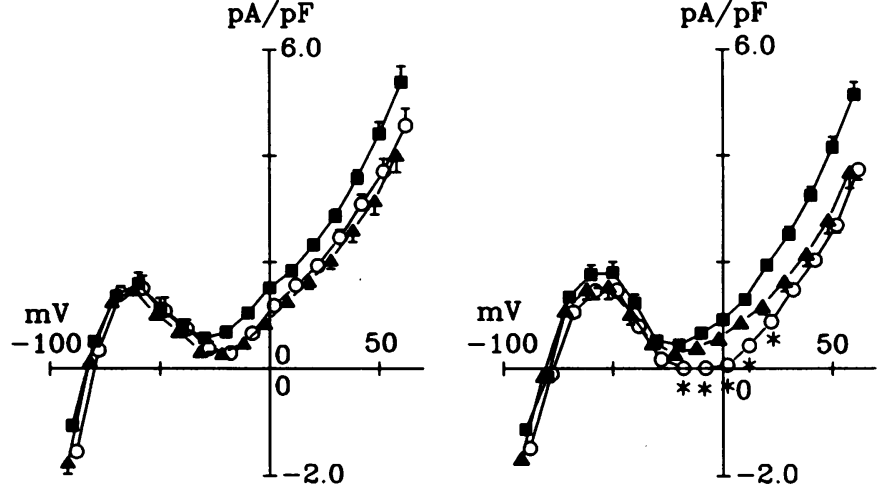

- Control

- $\mathrm{CN}^{-} 15 \mathrm{~min}$

o wO $10 \mathrm{~min}$
Figure 5. Effects of $\mathrm{CN}^{-}$and its washout on nonisolated membrane currents. $(A)$ Representative tracings of membrane currents in the control state (closed triangles), at 15 min after initiating superfusion with $\mathrm{CN}^{-}$-Tyrode's solution (closed squares), and at $10 \mathrm{~min}$ after initiating reperfusion with normal Tyrode's solution (open circles).

Membrane currents were elicited by 800-ms-long square pulses from a $V_{\mathrm{h}}$ of $-80 \mathrm{mV}$ to $V_{\mathrm{t}}$ between -90 and $+60 \mathrm{mV}$ (only traces to a $V_{\mathrm{t}}$ of $-10 \mathrm{mV}$ are shown). An inset on top of the panel shows a voltage-step protocol. Upper traces show membrane currents for a normal cell and lower traces for a hypertrophied cell. $(B)$ The steady state I-V relationships measured at $600 \mathrm{~ms}$ after the onset of depolarizing steps in the

control state (closed triangles), 15 min after initiating superfusion with $\mathrm{CN}^{-}$-Tyrode's solution (closed squares), and 10 min after initiating reperfusion with normal Tyrode's solution (open circles) in normal cells $($ left, $n=18)$ and in hypertrophied cells $($ right, $n=16)$. Negative shift of I-V curve during washout of $\mathrm{CN}^{-}$in hypertrophied cells.

The data in the present study reinforce the importance of lengthening of APD for the generation of EADs. In cells isolated from normal hearts, APD was slightly prolonged during reperfusion. This finding is in agreement with the data in multicellular ventricular muscle preparations or in vivo $(23,28)$; refractory periods and APDs in the previously ischemic region lengthen beyond preischemic values with sustained reperfusion of $>30 \mathrm{~s}$. It is clear that the lengthening of APD is much greater in cells isolated from hypertrophied hearts; furthermore, among the subgroup of hypertrophied cells, APD prolongation was significantly greater in cells that had developed EADs than those that had not.
The lengthening of APD should reflect the sum of the currents that flow within voltage range of the action potential plateau. These include $\mathrm{Na}^{+}$" window" current or slowly inactivating $\mathrm{Na}^{+}$current $(30,31), \mathrm{Ca}^{2+}$ current $(32,33), \mathrm{K}^{+}$current (34-38), and possibly $\mathrm{Na}^{+}-\mathrm{K}^{+}$pump (39) and $\mathrm{Na}^{+}-\mathrm{Ca}^{2+}$ exchange current (40). Alterations of one of more of these currents may modulate the duration of action potential plateau. In the present study steady state outward current within the voltage range of the action potential plateau was reduced during reperfusion in hypertrophied cells but not in normal cells. Under experimental conditions in which $I_{\mathrm{Ca}, \mathrm{L}}$ was isolated from other classes of currents, this reduction in steady
(A)

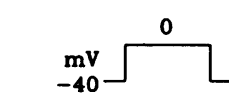

(B)

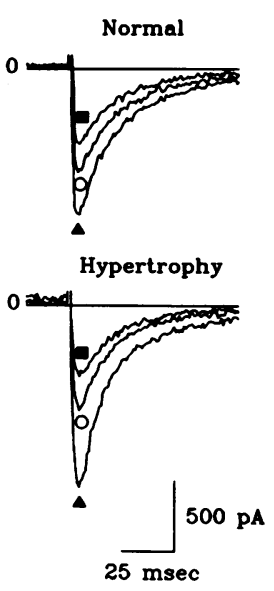

Normal $(n=19)$

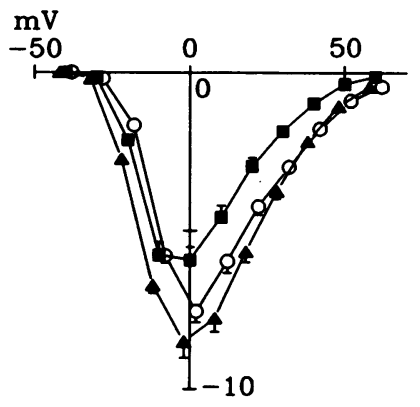

$\mathrm{pA} / \mathrm{pF}$

- Control

- $\mathrm{CN}^{-} 15 \mathrm{~min}$

○ WO $10 \mathrm{~min}$

Hypertrophy $(n=24)$

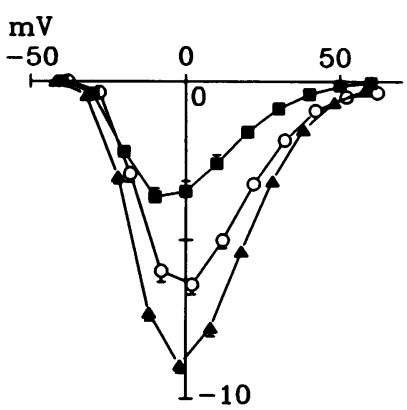

$\mathrm{pA} / \mathrm{pF}$ 10 min after initiating reperfusion with normal Tyrode's solution (open circles) in normal cells (left, $n=19$ ) and in hypertrophied cells (right, $n=24$ ).

Figure 6. Effects of $\mathrm{CN}^{-}$and its washout on peak amplitude of $I_{\mathrm{Ca}, \mathrm{L}}$. $(A)$ Representative tracings of early portion of $I_{\mathrm{Ca}, \mathrm{L}}$ in the control state (closed triangles), 15 min after initiating superfusion with $\mathrm{CN}^{-}-\mathrm{Ty}$ rode's solution (closed squares), and $10 \mathrm{~min}$ after initiating reperfusion with normal Tyrode's solution (open circles). $I_{\mathrm{Ca}, \mathrm{L}}$ was elicited by square pulses from a $V_{\mathrm{h}}$ of $-40 \mathrm{mV}$ to $V_{\mathrm{t}}$ between -90 and $+60 \mathrm{mV}$ for 800 $\mathrm{ms}$ (only traces to $0 \mathrm{mV}$ are shown). An inset on top of the panel shows a voltage-step protocol. (Top) Traces for a normal cell and lower panel for a hypertrophied cell. (B) The I-V relationships of negative peak of $I_{\mathrm{Ca}, \mathrm{L}}$ in the control state (closed triangles), 15 min after initiating superfusion with $\mathrm{CN}^{-}-\mathrm{Ty}-$ rode's solution (closed squares), and 
(A)
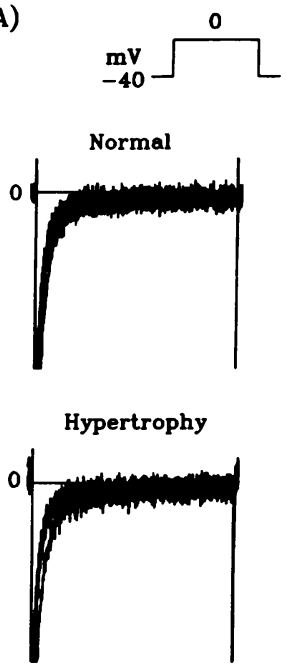

$100 \mathrm{pA}$

$200 \mathrm{msec}$
(B)

$$
\text { Normal }(n=19) \quad \text { Hypertrophy }(n=24)
$$
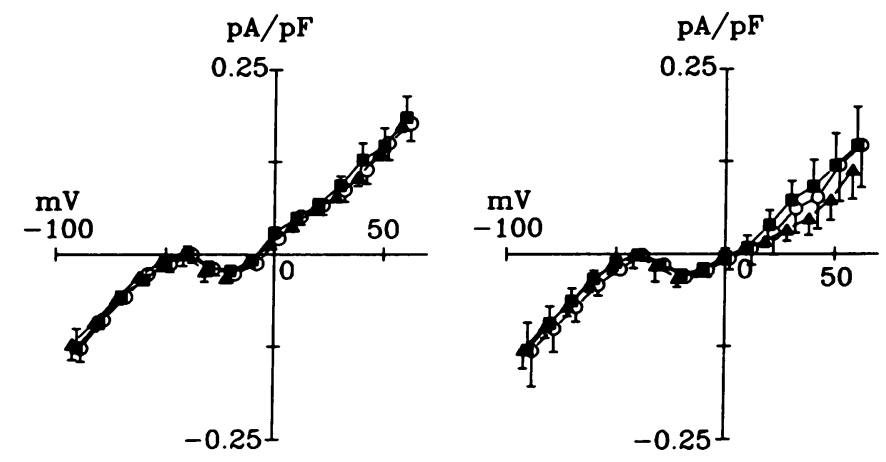

- Control

- $\mathrm{CN}^{-} 15 \mathrm{~min}$

o wo $10 \mathrm{~min}$

Figure 7. Effects of $\mathrm{CN}^{-}$and its washout on the steady state currents of $I_{\mathrm{Ca}, \mathrm{L}} \cdot(A)$ Representative tracings of superimposition of $I_{\mathrm{Ca}, \mathrm{L}}$ in the control state, $15 \mathrm{~min}$ after initiating superfusion with $\mathrm{CN}^{-}$-Tyrode's solution, and $10 \mathrm{~min}$ after initiating reperfusion with normal Tyrode's solution. $I_{\mathrm{Ca}, \mathrm{L}}$ was elicited by square pulses from a $V_{\mathrm{h}}$ of $-40 \mathrm{mV}$ to $V_{\mathrm{t}}$ between -90 and $+60 \mathrm{mV}$ for 800 $\mathrm{ms}$ (only traces to $0 \mathrm{mV}$ are shown). An inset on top of the panel shows a voltage-step protocol. (Top) Traces for a normal cell and lower panel for a hypertrophied cell. Please note that the current level of steady state $I_{\mathrm{Ca}, \mathrm{L}}$ in the control state, during superfusion with $\mathrm{CN}^{-}$, and its washout are almost identical. $(B)$ The I-V relationships of steady state $I_{\mathrm{Ca}, \mathrm{L}}$ measured at $600 \mathrm{~ms}$ from the onset of square pulses in the control
$10 \mathrm{~min}$ after initiating reperfusion state (closed triangles), 15 min after initiating superfusion with $\mathrm{CN}^{-}$-Tyrode's solution (closed squares), and 10 min afte
with normal Tyrode's solution (open circles) in normal cells (left, $n=19$ ) and in hypertrophied cells (right, $n=24)$.

state outward current was not observed, whereas under conditions in which pure $\mathrm{K}^{+}$current could be recorded without contamination of other classes of currents, reperfusion did result in the reduction in steady state outward current. We used rigorous methods to isolate $I_{\mathrm{Ca}, \mathrm{L}}$ or $\mathrm{K}^{+}$currents from other classes of currents during the reperfusion studies. To isolate $\mathrm{K}^{+}$current, for example, $\mathrm{Na}^{+}$current was eliminated by externally applied TTX $(12.5 \mu \mathrm{M}) . I_{\mathrm{Ca}, \mathrm{L}}$ and $I_{\mathrm{Ca}, \mathrm{T}}$ were eliminated by the addition of $0.1 \mathrm{mM} \mathrm{CdCl} 2$ and $0.1 \mathrm{mM} \mathrm{NiCl}$ to the bath solution, respectively. $\mathrm{Ca}^{2+}$-activated currents and the electrogenic
$\mathrm{Na}^{+}-\mathrm{Ca}^{2+}$ exchanger were blocked by omitting $\mathrm{Ca}^{2+}$ from the pipette solution and buffering $\mathrm{Ca}^{2+}$ with $10 \mathrm{mM}$ EGTA. Current through the electrogenic $\mathrm{Na}^{+}-\mathrm{K}^{+}$pump was abolished by the addition of ouabain to the external solution. Even if $\mathrm{Cd}^{2+}$ is not a specific $I_{\mathrm{Ca}, \mathrm{L}}$ blocker and exerts some blocking effect on $\mathrm{K}^{+}$channels (41), the latter effect does not appear to be quantitative and therefore the ability to observe the negative shift of steady state outward current under such conditions leads us to suggest a major contribution of $\mathrm{K}^{+}$currents in this phenomenon.
(A)
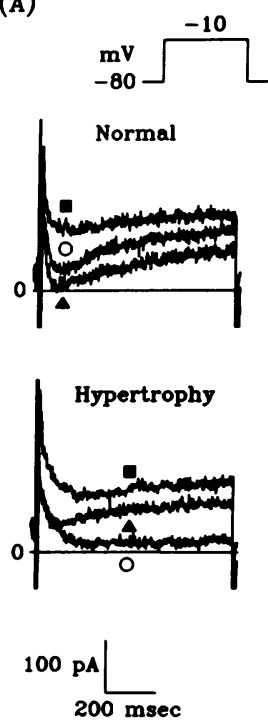

(B)
Normal $(n=12)$

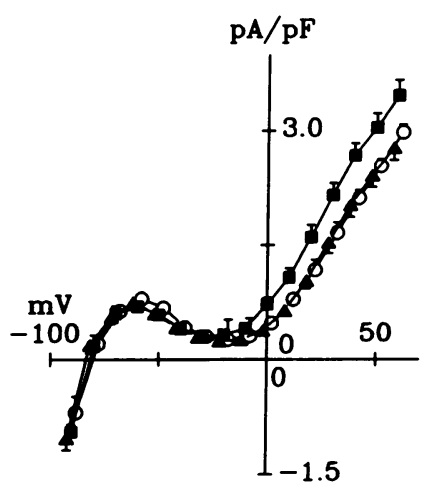

Hypertrophy $(n=12)$

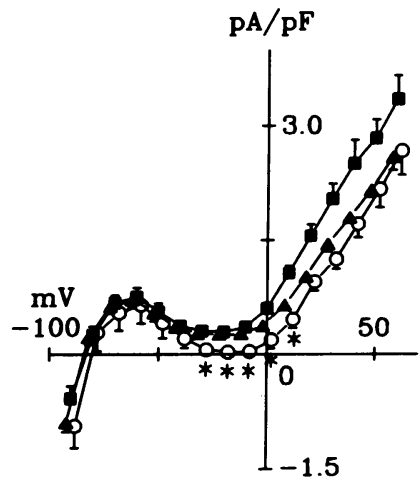

- Control

- $\mathrm{CN}^{-} 15 \mathrm{~min}$

○ $10 \mathrm{~min}$
Figure 8. Effects of $\mathrm{CN}^{-}$and its washout on the steady state $\mathrm{K}^{+}$ current. $(A)$ Representative tracings of $\mathrm{K}^{+}$currents in the control state (closed triangles), at $15 \mathrm{~min}$ after initiating superfusion with $\mathrm{CN}^{-}-\mathrm{Ty}$ rode's solution (closed squares), and at $10 \mathrm{~min}$ after initiating reperfusion with normal Tyrode's solution (open circles). $\mathrm{K}^{+}$currents were elicited by 800-ms long square pulses from a $V_{\mathrm{h}}$ of $-80 \mathrm{mV}$ to $V_{\mathrm{t}}$ between -90 and $+60 \mathrm{mV}$ (only traces to a $V_{\mathrm{t}}$ of -10 $\mathrm{mV}$ are shown). An inset on top of the panel displays a voltage-step protocol. Upper traces show membrane currents for a normal cell and lower traces for a hypertrophied cell. $(B)$ The I-V relationships of steady state $\mathrm{K}^{+}$current measured at $600 \mathrm{~ms}$ after the onset of depolarizing steps in the control state (closed triangles), 15 min after initiating superfusion with

$\mathrm{CN}^{-}$-Tyrode's solution (closed squares), and $10 \mathrm{~min}$ after initiating reperfusion with normal Tyrode's solution (open circles) in normal cells ( left, $n=12$ ) and in hypertrophied cells ( right, $n=12$ ). *Negative shift of $\mathrm{I}-\mathrm{V}$ curve during wash out of $\mathrm{CN}^{-}$in hypertrophied cells. 
It has been postulated that altered $\mathrm{K}^{+}$currents may also be responsible for the prolonged APD in hypertrophied myocytes (42). Thus, it appears that in hypertrophied cells the altered $\mathrm{K}^{+}$current characteristics in the basal state precondition the cells to respond to reperfusion differently from channels in normal cells. Recently, Kowey et al. (43) reported in an in vivo study that susceptibility to VF induced by electrical stimulation was markedly enhanced in cats with pressure overload compared with the control group. Risotilide, an inhibitor of the voltage-dependent $\mathrm{K}^{+}$channel, but not verapamil, reduced ventricular vulnerability concomitant with narrowed dispersion of the effective refractory period and monophasic action potential duration, suggesting reentry as a possible mechanism underlying electrically induced VF in cat ventricular hypertrophy. Thus, although alterations in $\mathrm{K}^{+}$channels appear to be a significant factor for the development of both electrically induced VF and reperfusion-related EADs, the arrhythmogenic mechanism involving $\mathrm{K}^{+}$channels in hypertrophied hearts may be different between the two cases. It should be noted that, even though our data suggest that $I_{\mathrm{Ca}, \mathrm{L}}$ may not be a primary factor for APD prolongation during reperfusion in hypertrophied cells, the contributions of $\mathrm{Na}^{+}$current, $I_{\mathrm{Ca}, \mathrm{T}}, \mathrm{Na}^{+}-\mathrm{Ca}^{2+}$ exchanges, or $\mathrm{Na}^{+}-\mathrm{K}^{+}$pump current were not completely excluded and require further study.

The negative shift of steady state outward $\mathrm{K}^{+}$current was prominent at a $V_{\mathrm{t}}$ range between -30 and $+20 \mathrm{mV}$ (see Fig. 8 $B)$. Among the classes of $\mathrm{K}^{+}$currents occurring in ventricular myocytes, the inward-rectifier $\mathrm{K}^{+}$current $\left(I_{\mathrm{k} 1}\right)$ contributes to membrane currents at a more negative voltage range (44). Transient outward $\mathrm{K}^{+}$current $\left(I_{\mathrm{to}}\right)$ activates and inactivates rapidly, and neither component contributes significantly to membrane current at $600 \mathrm{~ms}$ after the onset of depolarization (45). Thus, the most plausible contributor to the reduction of steady state outward current in this voltage range is the delayed rectifier $\mathrm{K}^{+}$current $\left(I_{\mathrm{k}}\right)$. Recently, Sanguinetti and Jurkiewicz (46) reported that $I_{\mathrm{k}}$ consists of two components, $I_{\mathrm{kr}}$ and $I_{\mathrm{ks}} \cdot I_{\mathrm{kr}}$ activates very rapidly relative to $I_{\mathrm{ks}}$, exhibits prominent inward rectification, and is observed mainly at potential between -20 and $+30 \mathrm{mV}$. The voltage range at which the reduction of steady state outward $\mathrm{K}^{+}$current was observed in the present study appears to correspond to the voltage range in which $I_{\mathrm{kr}}$ activates. Thus, it may be of interest to study the effects of the benzenesulfonamide antiarrhythmic agent, E-4031, a specific blocker of $I_{\mathrm{kr}}$, to determine whether $I_{\mathrm{kr}}$ is involved in the reduction of steady state outward current during reperfusion in hypertrophied cells. However, the existence of $I_{\mathrm{ks}}$ in cat myocytes is questioned because of the observation that tail currents of $I_{k}$ are completely suppressed in cat myocytes by this agent (47).

In summary, the data reported in this study are consistent with an evolving body of information leading to a general principle of the association between various factors that prolong APDs and lead to generation of EADs. Triggered activity resulting from EADs appears to lead to specific forms of clinical arrhythmias, such as torsades de pointes, rapid polymorphic VT, and possibly ventricular fibrillation. In such diverse clinical circumstances as classical proarrhythmic responses to class I-A and III antiarrhythmic drugs $(48,49)$, acute cocaine exposure $(50)$, and now reperfusion after ischemia in cells from hypertrophied hearts, the conditioning event, APD prolongation, appears to be due primarily to abnormalities in repolarizing $\mathrm{K}^{+}$currents (especially $I_{\mathbf{k}}$ ) whereas the EADs themselves are generated by $\mathrm{Ca}^{2+}$ (or perhaps slowly inactivating $\mathrm{Na}^{+}$) acting as the carrier current.

\section{Acknowledgments}

We thank Dr. P. L. Kozlovskis for helpful discussion during the course of these experiments, Mr. B. L. Wasserlauf for expert technical assistance, and Ms. Thelma L. Gottlieb for assistance in preparation of the manuscript.

This work was supported by Grants HL-19044 and HL-21735 from the National Heart, Lung, and Blood Institute and by Grants-in-Aid from American Heart Association, Miami Affiliate (A. L. Bassett, S. Kimura, R. J. Myerburg).

\section{References}

1. Gwathmey, J. K., and J. P. Morgan. 1985. Altered calcium handling in experimental pressure-overload hypertrophy in the ferret. Circ. Res. 57:836-843.

2. Bassett, A. L., and H. Gelband. 1973. Chronic partial occlusion of the pulmonary artery in cats: change in ventricular action potential configuration during early hypertrophy. Circ. Res. 32:15-26.

3. Aronson, R. S. 1980. Characteristics of action potentials of hypertrophied myocardium from rats with renal hypertension. Circ. Res. 47:443-454.

4. Sasayama, S., D. Franklin, and J. Ross, Jr. 1977. Hyperfusion with normal inotropic state of the hypertrophied left ventricle. Am. J. Physiol. 232:H418H425.

5. Mueller, T. M., M. L. Marcus, R. E. Kerber, J. A. Young, R. W. Barnes, and F. M. Abboud. 1978. Effect of renal hypertension and left ventricular hypertrophy on the coronary circulation in dogs. Circ. Res. 42:543-549.

6. Koyanagi, S., C. Eastham, and M. L. Marcus. 1982. Effect of chronic hypertension and left ventricular hypertrophy on the incidence of sudden cardiac death after coronary artery occlusion in conscious dogs. Circulation. 65:11921197.

7. Kohya, T., S. Kimura, R. J. Myerburg, and A. L. Bassett. 1988. Susceptibility of hypertrophied rat hearts to ventricular fibrillation during acute ischemia. $J$. Mol. Cell. Cardiol. 20:159-168.

8. Martins, J. B., W. Kim, and M. L. Marcus. 1989. Chronic hypertension and left ventricular hypertrophy facilitate induction of sustained ventricular tachycardia in dogs hours after left circumflex coronary artery occlusion. J. Am. Coll. Cardiol. 14:1365-1373.

9. Taylor, A. L., R. Winter, F. Thandroyen, S. Murphree, L. M. Buja, R. Eckels, P. Pastor, and M. Kremers. 1990. Potentiation of reperfusion-associated ventricular fibrillation by left ventricular hypertrophy. Circ. Res. 67:501-509.

10. Pogwizd, S. M., and P. B. Corr. 1987. Electrophysiologic mechanisms underlying arrhythmias due to reperfusion of ischemic myocardium. Circulation. 72:404-426.

11. Verrier, R. L., and E. Hagestad. 1986. Mechanisms of reperfusion arrhythmias. Eur. Heart J. 7(Suppl A):13-22.

12. Molina-Viamonte, V., E. P. Anyakhovsky, and M. R. Rosen. 1991. An alpha-adrenergic receptor subtype is responsible for delayed afterdepolarizations of isolated canine Purkine fibers. Circulation. 84:1732-1740.

13. Furukawa, T., A. L. Bassett, S. Kimura, N. Furukawa, and R. J. Myerburg. 1990. "Reperfusion" early afterdepolarizations (EAD) in hypertrophied feline myocytes: role of membrane currents. Circulation. 82(Suppl III):III-100. (Abstr.)

14. Cameron, J. S., R. J. Myerburg, S. S. Wong, M. S. Gaide, K. Epstein, T. R. Alvarez, H. Gelband, P. A. Guse, and A. L. Bassett. 1983. Electrophysiologic consequences of chronic experimentally induced left ventricular pressure overload. J. Am. Coll. Cardiol. 2:481-487.

15. Kimura, S., A. L. Bassett, T. Furukawa, J. Cuevas, and R. J. Myerburg. 1990. Electrophysiological properties and responses to simulated ischemia in cat ventricular myocytes of endocardial and epicardial origins. Circ. Res. 66:469477.

16. Fabiato, A., and F. Fabiato. 1979. Calculator programs for computing the composition of the solutions containing multiple metals and ligands used for experiments in skinned muscle cells. J. Physiol. (Paris). 75:463-505.

17. Hamill, O. P., A. Marty, E. Neher, B. Sakmann, and F. J. Sigworth. 1981. Improved patch-clamp techniques for high resolution current recording from cells and cell-free membrane patches. Pfluegers Arch. Eur. J. Physiol. 391:85100.

18. Hille, B. 1984. Ionic Channels of Excitable Membranes. Sinauer Associates Inc., Sunderland, England.

19. Hayashi, H., C. Ponnambalam, and T. F. McDonald. 1987. Arrhythmogenic activity in reoxygenated guinea pig papillary muscles and ventricular cells. Circ. Res. 61:124-133. 
20. Furukawa, T., S. Kimura, N. Furukawa, A. L. Bassett, and R. J. Myerburg. 1991. Role of cardiac ATP-regulated potassium channels in differential responses of endocardial and epicardial cells to ischemia. Circ. Res. 68:16931702.

21. Belles, B., C. O. Malecot, J. Hescheler, and W. Trautwein. 1988. "Rundown" of the Ca current during long whole-cell recordings in guinea pig heart cells: role of phosphorylation and intracellular calcium. Pfluegers Arch. Eur. J. Physiol. 411:353-360.

22. Corbalan, R., R. L. Verrier, and B. Lown. 1976. Differing mechanisms for ventricular vulnerability during coronary artery occlusion and release. Am. Heart J. 92:223-224.

23. Priori, S. G., M. Mantica, C. Napolitano, and P. J. Schwartz. 1990. Early afterdepolarizations induced in vivo by reperfusion of ischemic myocardium: possible mechanism for reperfusion arrhythmias. Circulation. 81:1911-1920.

24. Furukawa, T., R. J. Myerburg, N. Furukawa, S. Kimura, and A. L. Bassett. 1990. Ionic mechanism of increased susceptibility of hypertrophied feline myocytes to metabolic inhibition. Circulation. 82(Suppl III):III-522. (Abstr.)

25. Myerburg, R. J., K. M. Kessler, S. M. Mallon, M. M. Cox, E. deMarchena A. Interian, Jr., and A. Castellanos. 1992. Life-threatening ventricular arrhythmias in patients with silent myocardial ischemia due to coronary artery spasm. $N$. Engl. J. Med. 326:1451-1455.

26. Ferrier, G. R., M. P. Moffatt, and A. Lukas. 1983. Possible mechanisms of ventricular arrhythmias elicited by ischemia followed by reperfusion. Circ. Res 56:184-194.

27. Ben David, J., and D. P. Zipes. 1990. Alpha-adrenoreceptor stimulation and blockade modulates cesium-induced early afterdepolarizations and ventricular tachyarrhythmias in dogs. Circulation. 82:225-233.

28. Hanich, R. F., J. H. Levine, J. F. Spear, and E. N. Moore. 1988. Autonomic modulation of ventricular arrhythmia in cesium chloride-induced longQT syndrome. Circulation. 77:1149-1161.

29. Kimura, S., A. L. Bassett, N. C. Saoudi, J. S. Cameron, P. L. Kozlovskis, and R. J. Myerburg. 1986. Cellular electrophysiologic changes and "arrhythmias" during experimental ischemia and reperfusion in isolated cat ventricular myocardium. J. Am. Coll. Cardiol. 7:833-842.

30. Coulombe, A., E. Coraboeuf, C. Malecot, and E. Deroubaix. 1985. Role of the "Na window" current and other ionic currents in triggering early afterdepolarization and resulting re-excitation in Purkinje fibers. In D. P. Zipes and J. Jalife, editors. Cardiac Electrophysiology and Arrhythmias. Grune \& Stratton, Inc., New York. 43-49.

31. Wasserstrom, J. A., and J. J. Salata. 1988. Basis for tetrodotoxin and lidocaine effects on action potentials in dog ventricular myocytes. Am. J. Physiol. 254 (Heart Circ. Physiol. 23):H1157-H1166.

32. January, C. T., J. M. Riddle, and J. J. Salata. 1988. A model for early afterdepolarization: induction with the $\mathrm{Ca}^{2+}$ channel agonist Bay K 8644. Circ. Res. 62:563-571.

33. January, C. T., and J. M. Riddle. 1989. Early afterdepolarizations: mechanism of induction and block. A role for L-type $\mathrm{Ca}^{2+}$ current. Circ. Res. 64:977990.

34. Damiato, B. P., and M. R. Rosen. 1984. Effect of pacing on triggered activity induced by early afterdepolarizations. Circulation. 69:1013-1025.
35. Brachmann, J., B. J. Scherlag, L. V. Rosenshtraukh, and R. Lazzara. 1983. Bradycardia-dependent triggered activity: relevance to drug-induced multiform ventricular tachycardia. Circulation. 68:846-856.

36. Roden, D. M., and B. F. Hoffman. 1985. Action potential prolongation and induction of abnormal automaticity by low quinidine concentrations in canine Purkinje fibers. Relationship to potassium and cycle length. Circ. Res. 56:857-867.

37. Kaseda, S., R. F. Gilmour, Jr., and D. P. Zipes. 1989. Depressant effect of magnesium on early afterdepolarizations and triggered activity induced by cesium, quinidine, and 4-aminopyridine in canine cardiac Purkinje fibers. Am. Heart J. 118:458-566.

38. Scherlag, B., B. Szabo, E. Patterson, and R. Lazzara. 1990. Cesium-induced early afterdepolarizations and triggered activity in intact animals and isolated tissues. In M. R. Rosen, M. J. Janse, and A. L. Wit, editors. Cardiac Electrophysiology: a Textbook. Futura Publishing Co., Inc., Mount Kisco, NY. 355370.

39. Gadsby, D. C., J. Kimura, and A. Noma. 1985. Voltage dependence of $\mathrm{Na} / \mathrm{K}$ pump current in isolated heart cells. Nature (Lond.). 315:63-65.

40. Kimura, J., A. Noma, and H. Irisawa. 1986. Na-Ca exchange current in mammalian heart cells. Nature (Lond.). 319:596-597.

41. Follmer, C. H., N. J. Lodge, C. A. Cullinan, and T. J. Colatsky. 1992. Modulation of the delayed rectifier, $\mathrm{I}_{\mathbf{k}}$, by cadmium in cat ventricular myocytes. Am. J. Physiol. 262:75-83.

42. Kleiman, R. B., and S. R. Houser. 1989. Outward currents in normal and hypertrophied feline ventricular myocytes. Am. J. Physiol. 256 (Heart Circ. Physiol. 25):H1450-H1461.

43. Kowey, P. R., T. D. Friehling, J. Sewter, Y. Wu, A. Sokil, J. Paul, and J. Nocella. 1991. Electrophysiological effects of left ventricular hypertrophy. Effect of calcium and potassium channel blockade. Circulation. 83:2067-2075.

44. Shah, A. K., I. S. Cohen, and N. B. Datyner. 1987. Background $\mathrm{K}^{+}$current in isolated canine cardiac Purkinje myocytes. Biophys. J. 52:519-525.

45. Furukawa, T., R. J. Myerburg, N. Furukawa, A. L. Bassett, and S. Kimura. 1990. Differences in transient outward currents of feline endocardial and epicardial myocytes. Circ. Res. 67:1287-1291.

46. Sanguinetti, M. C., and N. K. Jurkiewicz. 1990. Two components of cardiac delayed rectifier $\mathrm{K}^{+}$current. J. Gen. Physiol. 96:195-215.

47. Follmer, C. H., and T. J. Colatsky. 1990. Block of delayed rectifier potassium current, $\mathrm{I}_{\mathrm{k}}$, by flecainide and E-4031 in cat ventricular myocytes. Circulation. 82:289-293.

48. Roden, D. M., P. B. Bennett, D. J. Synders, J. R. Balser, and L. M Hondeghem. 1988. Quinidine delays $\mathbf{I}_{\mathbf{k}}$ activation in guinea pig ventricular myocytes. Circ. Res. 62:1055-1058.

49. Kadish, A. H., and F. Morady. 1990. Torsade de pointes. In Cardiac Electrophysiology: from Cell to Bedside. D. P. Zipes and J. Jalife, editors. W. B. Saunders Co., Philadelphia. 605-610.

50. Kimura, S., A. L. Bassett, H. Xi, and R. J. Myerburg. 1992. Early afterdepolarizations and triggered activity induced by cocaine: a possible mechanism of cocaine arrhythmogenesis. Circulation. 85:2227-2235. 